\title{
Modeling the Relationship between FDI and Financial Development in Small Island Economies: A PVAR Approach
}

\author{
Sheereen Fauzel \\ University of Mauritius, Moka, Mauritius \\ Email: s.fauzel@uom.ac.mu
}

Received 23 February 2016; accepted 28 May 2016; published 31 May 2016

Copyright (C) 2016 by author and Scientific Research Publishing Inc.

This work is licensed under the Creative Commons Attribution International License (CC BY). http://creativecommons.org/licenses/by/4.0/

\begin{abstract}
FDI is considered as an important source of capital investment for small island economies and is considered as a crucial tool for attaining economic growth and development. Most studies that have been done relating to foreign direct investment (FDI) are rather on the link between FDI and economic growth or even the link between FD and economic growth. Certainly, there is sufficient theoretical rationale to ascertain that FDI does influence the development of financial market of the recipient countries. Hence, basing on the argument that there is a lack of studies done in this area mainly for the case of small island economies, this paper uses a panel vector autoregressive model (PVAR) which caters for both endogeneity and dynamism, and investigates the relationship between FDI and FD over the time period spanning from 1990 to 2013. Actually, the study shows that FDI can be an important ingredient for developing the financial market in small island economies. For instance, a bi-causal relationship between FDI and FD is observed from the results. Also, economic growth has been identified to play a crucial role in boosting financial development in this study. Moreover other interesting relationships have been detected in the PVAR model.
\end{abstract}

\section{Keywords}

Financial Development, FDI, Causality, PVAR

\section{Introduction}

Foreign direct investment is considered as an important ingredient to boost economic growth and development of small island developing states (SIDS). Moreover, it is considered as a crucial source of investment capital. SIDS are mainly small economies having a small domestic market.

It is observed that FDI has been flowing more significantly in the Caribbean SIDS mainly due to their prox- 
imity to large American markets. Nevertheless, SIDS located in Africa, Asia and Oceania have also been performing well and have registered relatively higher FDI growth during the 2000s.

In fact, SIDS have a limited domestic resource base, and a high degree of structural openness to trade. These economies have been able to attract foreign investment mainly because of several advantages. For instance, they have trade preferences regimes that give them principally preferential access to markets of developed countries. Also, oceans, sizeable exclusive economic zones, coastal environments and biodiversity have attracted FDI to tourism and fishing activities. Large nonrenewable natural resources have stimulated large foreign investments in mining and related downstream activities in some of these countries. These economies also have limited institutional and financial capacities to manage and use natural resources on a sustainable basis. It is also observed that some of them are endowed with natural resources as well as human resources. For example, SIDS like Papua New Guinea, Trinidad and Tobago, and Timor-Leste are resource rich. Foreign investors from developing economies have invested mainly on Papua New Guinea, Maldives, Mauritius and Jamaica.

In addition to that, SIDS provide various powerful incentives for foreign firms to create headquarters, financial and trading operations. All these incentives have encouraged FDI in the business and offshore financial services (UNCTAD, 2013). Hence, one can argue that FDI can help the small island developing states to develop their financial market. Regarding the state of financial market development for SIDS, Singapore and Bahrain have a high level of financial development. However, there are some other SIDS having low levels of financial market development. These economies thus face challenges in mobilizing financing effectively, both domestically and internationally.

So far, most studies have been focusing on the relationship between FDI and economic growth or even financial development and economic growth. There are limited studies on the link between FDI and financial market development and even less on the investigation of the causality direction between them for small island eonomies. More so, the issue of dynamics and endogeneity has been rarely examined.

The aim of this study is therefore to analyze the link between FDI and financial market development for small island economies. This paper is believed to depart from and contribute to the existing literature in several ways. A dynamic panel analysis is being employed for this investigation. Indeed, a Panel Vector Autoregressive Model (PVAR) is used intensively to determine the relationship between FD and FDI while simultaneously allowing identification of any bi-directional and/or uni-directional causality between the variables of interest. Moreover, this particular model discloses both the direct and the indirect impacts, if any, which FDI might have on financial market development. Also, the determinants of both the financial market development and FDI can be analyzed through the PVAR model.

The paper is organized as follows: Section 2 presents the literature review followed by the methodology and findings in Section 3. Section 4 presents the conclusion.

\section{Literature Review}

Studies on foreign direct investment, financial development and economic growth in the literature have been predominantly based on the relationship between FDI and economic growth and the impact of financial development on economic growth.

Reviewing the literature on the impact of FD and economic growth, McKinnon [1] opined that liberalisation of financial markets enables financial deepening reflecting an increase in the use of financial intermediation by savers and investors and the monetisation of the economy thus aiding the efficient flow of resources among people and institutions over time. Consequently, savings is encouraged, constraints on capital accumulation are reduced and allocative efficiency of investment is improved which is led by a transfer of capital from less productive to more productive sectors. The author further mentioned that the efficiency and the level of investment is expected to increase with the financial development that liberalisation endorses.

Importantly, development in the financial system smoothens portfolio diversification for savers by reducing risk as well as proposes vaster options of boosting returns to investors. Additionally, as put forward by King \& Levine [2], a vital characteristic of a financial system is to gather and process information on (productivity-enhancing) investment projects in a cost effective manner that aids in reducing cost of investment for individual investors. Both capacity utilization and installed capacity is of utmost importance as the productive capacity of the economy is determined by the quantity of investment without omitting its quality. The efficiency of resource allocation is expected to improve by diminishing credit constraint, in particular working capital, which ultimately 
leads to a reduction in the gap between actual and potential output.

\section{Relationship between FDI and Financial Development (FD)}

Remarkably, the literature does not provide much clarity on the possible direct causality between FDI and FD. The few papers aiming at addressing this issue focus on how FD aids in channeling FDI into economic production including analysis of specific regions as well [2]-[6]. Adam and Tweneboah [7] studied the long-run relationship between FDI and stock market development in Ghana while Al Nasser and Soydemir [8] conducted Granger causality tests between FDI and financial development variables for Latin American countries.

Despite Alfaro et al. [3], [9] reported that FDI is a stronger contributing factor towards growth in developed financial market, the interaction between FDI and FD has not been clearly established, particularly in the African continent where the financial markets are still at the very developmental stage. Given the lack of studies on the direct causal relationship between FDI and FD, recourse is taken to the numerous existing theoretical rationales for expecting same.

Importantly, a rise in FDI net inflows would impact positively on the economic activities of a country leading to an increase in funds available in the economy. Consequently, financial intermediation through available financial markets or the banking system would enhance, as reported by Desai et al. (2006) and Henry [10]. Additionally, it is probable that companies which are involved in FDI are to be listed on local stock exchanges. The rationale is that it is a tradition to gain financing through the stock market for industrialised countries where it is imperative for any company to access stock exchanges in order to improve its image vis-à-vis investors.

Furthermore, by using a political economic analysis, Kholdy and Sohrabian [2] [6] and Rajan and Zingales [11] argued that a rise in FDI would decrease the relative power of the elites in the economy which can encourage them to adapt to market friendly regulations leading to a stronger financial sector. Henry [10] advised that foreign investors are attracted to well-functioning financial markets implying openness from countries authorities, sign of vitality and market friendly environment which urge them to make further investment in the country. Moreover, the liquidity of listed companies is higher in a relatively developed stock market which leads to a reduction in the cost of capital that make the country attractive to foreign investments (Desai et al., 2006 and Henry [10]). A theoretical rationale is deduced from each of these arguments for the positive relationship between FDI and financial development.

This topic is more relevant in the African context as African stock markets differ in terms of the levels of development and the majority involves low liquidity and less transparency. Beck et al. [12] argued that the shallowness of finance and the absence of developed financial market in Africa have reduced economic growth on the continent. Importantly, FDI can be a motivation for financial market reforms in the African continent and can also act as a vital tool to enhance liquidity, transparency and depth of the markets. On the other hand, a more efficient allocation of foreign investments can be expected of the continent into productive sectors that would generate more value for foreign investors and ultimately lead to a rise in foreign investments.

Beck et al. [12] used granger causality tests and multivariate analyses and concluded the bidirectional positive relationship between FDI and FD. They added that FDI impacts positively and significantly on economic growth in the African continent when the simultaneous effects of both FDI and FD are controlled. Thus, it is important that further studies involving both FDI and FD should account for this potential endogeneity issue.

Alfaro et al. [3] and Hermes and Lensink [5], among many others, have demonstrated the importance of the development of the financial system of a country towards channeling FDI to more productive sectors of the economy. Dutta and Roy [4] and Kholdy and Sohrabian [2] [6] argued that the coexistence of advanced financial markets and political stability are vital to capture the benefits of FDI. Other studies carried out on market liberalization and alleviation of capital control contributes towards this topic because if capital controls and financial repression is viewed as characteristics of an underdeveloped financial sector, capital market liberalization can be evidence of a leap towards financial development.

Consistent with the above, Henry [10] concluded that financial liberalization leads to a rise in the growth rate of private investment as well as FDI. Desai et al. (2006) added that higher interest rates as a result of a rise in capital control increase the cost of capital which in turn discourages FDI. They mentioned that interest rates increase due to the majority source of funding for local affiliates of multinational investors which emanates from the local debt markets.

Moreover, trade openness can also increase financial development mainly through the direct channel which is 
an increase in the size of markets and financial services due to openness. In this perspective, an increase in trade openness may lead to a supply of new financial instruments whereby, financial institutions are expected to evolve so as to provide more adequate insurance and risk diversification [13].

Empirically, the link between FDI and FD is impacted by cost of capital as financial development reduces same and thus increase investments in local companies or local affiliates of multinationals. However, a direct link between FDI and FD has not been clearly established particularly for small island economies.

\section{Methodology}

\subsection{Model Specification}

The aim of the paper strives towards investigating the link between foreign direct investment and financial development of a panel of small island economies ${ }^{1}$. Following Levine et al. [14] [15] and Levine and Zervos (1997), the proxy used to measure financial development is the ratio of domestic credit to private sector expressed as a percentage of GDP. The time period considered is from 1990 to 2013 . There are various studies which have been done on the relationship between FDI and economic growth in Mauritius [16] or even on financial development and economic growth [17] or Allen et al. [18] for Africa. However, studies on the relationship between FDI and financial development are rather scant. The regression model adopted to measure this relationship is as follows;

$$
\mathrm{FD}=a_{0}+a_{1} \mathrm{FDI}_{i t}+a_{2} \mathrm{GDP}_{i t}+a_{3} \mathrm{GFCF}_{i t}+a_{4} \mathrm{EDU}_{i t}+a_{5} \mathrm{OPEN}_{i t}+a_{6} \mathrm{INTRATE}_{i t}+a_{7} \mathrm{GDPDEF}_{i t}+\mu_{i t}
$$

In a later stage in the investigation the following two relationships will be analyzed. The regression models are as follows;

$$
\begin{aligned}
& \mathrm{FDI}=b_{0}+b_{1} \mathrm{FD}_{i t}+b_{2} \mathrm{GDP}_{i t}+b_{3} \mathrm{GFCF}_{i t}+b_{4} \mathrm{EDU}_{i t}+b_{5} \mathrm{OPEN}_{i t}+b_{6} \mathrm{INTRATE}_{i t}+b_{7} \mathrm{GDPDEF}_{i t}+\mu_{i t} \\
& \mathrm{GDP}=c_{0}+c_{1} \mathrm{FDI}_{i t}+c_{2} \mathrm{FD}_{i t}+c_{3} \mathrm{GFCF}_{i t}+c_{4} \mathrm{EDU}_{i t}+c_{5} \mathrm{OPEN}_{i t}+c_{6} \mathrm{INTRATE}_{i t}+c_{7} \mathrm{GDPDEF}_{i t}+\mu_{i t}
\end{aligned}
$$

The second equation will examine whether development of the financial market attracts foreign investment and the third equation will investigate the extent to which foreign investment and financial development influences economic growth.

All the variables have been expressed in their natural logarithm form so as to ease comparison and offer better interpretations.

\subsection{Dependent Variable: Financial Development}

There are various measures of financial development that has been used in the literature. For instance, the ratio of total credit granted by financial intermediaries to the private sector to GDP is used as well as liquid liabilities of the financial system or the ratio of commercial bank assets divided by commercial bank plus central bank assets. These variables measure the level of accessibility and use of the financial services. Regarding stock market development, authors like Levine and Zervos (1997), Allen et al. [18] and Allen, Otchere and Senbet [19] used the ratio of the total stock market capitalisation over GDP, or even the stock market turnover ratio and the total stock market value traded.

In this study, the proxy used to measure the financial development is the following;

\section{$>$ Domestic credit to private sector expressed as a percentage of GDP (FD)}

Following Baltagi et al. [20], the ratio of domestic credit to private sector expressed as a percentage of GDP is used to measure financial development. This ratio is defined as follows; "domestic credit to private sector refers to financial resources provided to the private sector by financial corporations, such as through loans, purchases of non-equity securities, and trade credits and other accounts receivable, that establish a claim for repayment. These claims include credit to public enterprises depending on different countries. The financial corporations include monetary authorities and deposit money banks, as well as other financial corporations where data are available (including corporations that do not accept transferable deposits but do incur such liabilities as time and savings deposits). Examples of other financial corporations are finance and leasing companies, money lenders, insurance corporations, pension funds, and foreign exchange companies” by the world bank.

${ }^{1}$ SIDS countries considered under this study: Antigua and Barbuda, Aruba, Bahamas, Bahrain, Belize, Comoros, Cyprus, Dominican Republic, Dominica, Grenada, Guyana, Jamaica, St Lucia, St Vincent and Grenadines, Malta, Papua New Guinea, Maldives, Mauritius. 


\subsection{Control Variables}

\section{Foreign Direct Investment}

Foreign direct investment is used as a measure of foreign presence in the country. In this study the proxy used to capture foreign investment is FDI inflows to GDP. It is expected that as foreign investment increases in a country the greater will be the development of the financial sector.

> GDP per Capita: The GDP per capita is used as a proxy for measuring economic growth in the country. The higher the growth rates the better will be financial development in the country.

> Human Capital: To capture the quality of human capital in a particular country, some studies have used the UNESCO's Gross Enrolment Ratio. Others have been using the literacy rate or even the secondary enrolment ratio. The education level of a country is an important tool for financial development of an economy. In this study, the secondary enrolment ratio is used.

$>$ Openness: Irrespective of other studies who used trade ratios to capture trade openness, this study follows Baltagi et al. [20] and Hanh [21] and trade openness level is measured by the ratio of the sum of imports and exports to GDP. This is the most widely used proxy for trade openness. Moreover, the measure is popular because data are readily available for many countries and also frequently used.

> Local Investment: Domestic level of investment can as well have an impact on financial development of a country. Hence, the GFCF to GDP is used to capture this variable.

> Interest Rate: The lending interest rate adjusted for inflation is used as a proxy for the efficiency of financial markets. High real interest rate can impede banks' lending activities.

> Inflation: The GDP deflator is used here and is a proxy for macroeconomic stability represented by GDPDEF in the regression equations.

Data has been extracted from the World Bank database, United Nations Educational, Scientific, and Cultural Organization (UNESCO) Institute for Statistics, International Monetary Fund, Balance of Payments Statistics Yearbook and data files and International Financial Statistics.

\subsection{Estimation Issues}

Before estimating the equation, it is important to test whether the variables are stationary or not. For this purpose, the Levin, Lin, Chu test and the Im, Pesaran, Shin test is being used. Levin-Lin-Chu Test (LLC) suggests the following hypotheses;

H0: each time series contains a unit root

H1: each time series is stationary

where the lag order $p$ is permitted to vary across individuals. The procedure works as follows:

$$
\Delta y_{i t}=p_{i} y_{i, t-1}+\sum_{L=1}^{p t} \theta_{i L} \Delta y_{i t-L}+\alpha_{m i} d_{m t}+\varepsilon_{i t}
$$

for $i=1, \cdots, N$ and $t=1, \cdots, T$, where $y_{i t}$ is the variable to be tested for unit root, $i$ is for the country, $t$ for the time, $\varepsilon_{i t}$ follows a normal distribution $N\left(0, \sigma^{2}\right), \alpha_{i}$ is the constant.

The Im-Pesaran-Shin (IPS) test is not as restrictive as the Levin-Lin-Chu test, since it allows for heterogeneous coefficients. The null hypothesis is that all individuals follow a unit root process:

$$
H_{0}: \rho_{i}=0 \forall i
$$

The alternative hypothesis allows some (but not all) of the individuals to have unit roots:

$$
H_{1}:\left\{\begin{array}{l}
\rho_{i}<0 \text { for } i=1,2, \cdots, N_{1} \\
\rho_{i}=0 \text { for } i=N_{1}+1, \cdots, N
\end{array}\right.
$$

Both the stationarity tests suggest that the first differences of the variables are integrated of order 1 and thus stationary. The results are shown in the Table 1.

\subsection{Panel Vector Autoregressive Model}

A panel vector autoregressive approach (PVAR) has been used in this study. This method has clear practical 
Table 1. Unit root test.

\begin{tabular}{|c|c|c|c|c|}
\hline & \multicolumn{2}{|c|}{ LEVIN, LIN, CHU } & \multicolumn{2}{|c|}{ IM, PESARAN, SHIN } \\
\hline & $\begin{array}{l}\text { Individual Intercept } \\
\text { First Difference }\end{array}$ & $\begin{array}{c}\text { Individual Intercept \& Trend } \\
\text { First Difference }\end{array}$ & $\begin{array}{l}\text { Individual Intercept } \\
\text { First Difference }\end{array}$ & $\begin{array}{c}\text { Individual Intercept \& Trend } \\
\text { First Difference }\end{array}$ \\
\hline Ln_FD & $-6.64284^{* * *}$ & $-4.81507^{* * *}$ & $-8.26681^{* * *}$ & $-5.98995^{* * *}$ \\
\hline Ln_FDI & $-10.5625^{* * *}$ & $-8.14524^{* * * *}$ & $-12.0784^{* * *}$ & $-10.1812^{* * *}$ \\
\hline Ln_GDP & $-6.00220^{* * *}$ & $-5.19589^{* * *}$ & $-6.19252^{* * *}$ & $-4.14603^{* * *}$ \\
\hline Ln_GFCF & $-8.95539^{* * *}$ & $-7.24783^{* * *}$ & $-8.67623^{* * *}$ & $-6.03586^{* * *}$ \\
\hline Ln_INTRATE & $-16.7560^{* * *}$ & $-15.4771^{* * *}$ & $-15.4894^{* * *}$ & $-11.3131^{* * *}$ \\
\hline Ln_HC & $-6.34597^{* * *}$ & $-4.11305^{* * *}$ & $-7.91008^{* * *}$ & $-6.35944^{* * *}$ \\
\hline Ln_OPEN & $-13.9281^{* * *}$ & $-11.4395^{* * *}$ & $-13.7365^{* * *}$ & $-11.1656^{* * *}$ \\
\hline Ln_GDPDEF & $-8.47886^{* * * *}$ & $-7.71992^{* * * *}$ & $-10.3497^{* * *}$ & $-8.14734^{* * *}$ \\
\hline
\end{tabular}

${ }^{*}$ Indicates the significance at $10 \%,{ }^{* *}$ significance at $5 \%$ and ${ }^{* * *}$ significance at $1 \%$.

advantages as an explicit dynamic system which is the most suitable way of investigating macroeconomic dynamics. PVAR imposes a statistical model on the contemporary movements of the variables rather than being driven by a particular macroeconomic concept. Also, PVAR does not distinguish between exogenous and endogenous variables, but rather treats all variables as jointly endogenous. Moreover, each variable in the PVAR depends on its past realization and on all other variables, suggesting a true simultaneity among them and their treatment on equal footing. Importantly, PVAR permits modeling both the endogenous and exogenous shocks which are the main sources of macroeconomic dynamics in small open economies.

\subsection{Endogeniety Issues}

Levine et al. [14] argued that there might still be the possibility of the loss of dynamic information even in panel data framework as the dependent variable may have something to do in explaining itself as well. It is likely that there exists dynamic feedbacks and indirect effects among the variables in the regression function. Including these feedbacks are essential to the modelling of the hypotheses. Given the possibility of endogeneity and causality issues the use of vector auto regressions (VAR) on panel data is made to investigate the complex relationship that might exist between FDI and FD. Moreover, Panel data vector auto regression combines the traditional VAR approach, which treats all the variables in the system as endogenous, with the panel data approach, which allows for unobserved individual heterogeneity. Hence, the first order VAR model is specified below:

$$
Z_{i t}=\Gamma_{0}+\Gamma_{1} Z_{i t}-1+\mu_{i}+\varepsilon_{t}
$$

where $z_{t}$ is a eight variable vector (LFD, LFDI, LGDP, LGFCF, LED, LOPEN, LINTRATE, LGDPDEF) and the variables are as defined previously. We use $i$ to index countries and $t$ to index time, $\tau$ are the parameters and $\varepsilon$ is the error term.

The result from the PVAR is shown in Table 2.

Table 2 is a composite table where each equation can be viewed and analysed as an independent function. For instance, of primarily interest is column 2 which the FD equation. An analysis of the results shows that foreign investment in small island economies has positively contributed to the development of the financial market. This result is in line with Hanh [21] whose results shows that financial development as measured by domestic credit to private sector enters the equation with a positive and significant coefficient.

There are other interesting results that can be seen from the above table. For instance, it is noted that economic growth of the small island economies, also have a positive and significant impact on the financial development of the countries. Similar results were obtained by King \& Levine [2] and Hanh [21]. There is strong conviction that economic growth plays an important role in financial development. 
Table 2. Results from PVAR.

\begin{tabular}{ccccccccc}
\hline & LN_FD & LN_FDI & LN_GDP & LN_GFCF & LN_INTRATE & LN_HC & LN_OPEN & LN_GDPDEF \\
\hline LN_FD(-1) & $0.6497^{* *}$ & $0.1665^{*}$ & -0.0047 & $-0.0267^{* *}$ & $-0.1697^{* *}$ & $-0.0003^{* * *}$ & $0.0197^{* * *}$ & $-0.0260^{* * *}$ \\
LN_FDI(-1) & $0.0329^{* *}$ & $0.6326^{* *}$ & $0.0058^{* * *}$ & $0.0149^{* * *}$ & $-0.0908^{* *}$ & $0.0049^{* * *}$ & $-0.0015^{* * *}$ & $-0.0011^{* * *}$ \\
LN_GDP(-1) & $0.0929^{* *}$ & $0.0311^{* *}$ & $1.0009^{* * *}$ & $-0.0050^{* *}$ & $-0.0469^{* *}$ & $0.0004^{* * *}$ & $-0.0136^{* * *}$ & $0.0107^{* * *}$ \\
LN_GFCF(-1) & -0.0458 & 0.2221 & $0.0041^{* * *}$ & $0.8857^{* *}$ & 0.0867 & $0.0003^{* *}$ & $-0.0277^{* * *}$ & $0.0222^{* * *}$ \\
LN_INTRATE(-1) & $-0.0648^{* *}$ & $-0.1119^{* *}$ & 0.0105 & $0.0136^{* *}$ & $0.2246^{* *}$ & $-0.0020^{* * *}$ & -0.0053 & 0.0099 \\
LN_HC(-1) & $0.1703^{* *}$ & 0.3097 & $0.0083^{* * *}$ & $0.0455^{* *}$ & 0.3056 & $0.9336^{* * *}$ & 0.0048 & -0.0291 \\
LN_OPEN(-1) & $0.0694^{* *}$ & $0.0102^{* *}$ & -0.0021 & $0.0126^{* *}$ & 0.0045 & 0.0003 & $0.9929^{* * *}$ & -0.0016 \\
LN_GDPDEF(-1) & $-0.0168^{* *}$ & $-0.0279^{* *}$ & $-0.0099^{* * *}$ & 0.0043 & -0.2007 & -0.0001 & -0.0033 & $0.9711^{* * *}$ \\
Constant & -0.2719 & -2.0300 & $0.0795^{* *}$ & 0.1636 & 2.1160 & $0.2965^{* *}$ & 0.1785 & $0.2207^{* *}$ \\
$\mathbf{R}^{2}$ & 0.75 & 0.71 & 0.99 & 0.86 & 0.17 & 0.97 & 0.99 & 0.99
\end{tabular}

*Indicates the significance at $10 \%,{ }^{* *}$ significance at $5 \%$ and ${ }^{* * *}$ significance at $1 \%$.

Moreover, an increase in trade openness can lead to more financial development as it may lead to an increase in the supply of new financial instruments [13]. The present study supports this idea. Analysing the results, it is observed that there is a positive and significant relationship between trade openness and financial development for the sample of small island developing states included in the study. Moreover, the results are also in line with Abida et al. [22]. Their study was on an examination of whether financial development helps a country to benefit more from trade openness. Their results shows that trade openness when interacted with the financial development indicators; the interaction terms are generally positive and significant, shedding light on the role of financial development in benefiting from trade openness. Hence, the more open an economy is, the better will be the financial development of the country.

Regarding human capital and financial development, it is noted that the study of Outreville [23], found high correlations between measures of financial development and human capital. According to this study, the result shows that indeed human capital has played a role in boosting financial development. A $1 \%$ increase in human capital has indeed led to a $0.17 \%$ increase in financial development for the set of countries included in the panel.

Additionally, poor macroeconomic performance has been identified to have detrimental effects on financial development of the country. Hence, an economy having a low and stable inflation will achieve a deeper and more active financial sector and other benefits attached to it [24]. The results are in favour of this proposition. Indeed an increase in inflation rate has a negative impact on the development of the financial sector.

The results further supports the fact that high real interest rate can hamper the lending activities of banks thereby affecting the development of the financial sector. Also, domestic investment in a country can play a significant role in promoting the financial development. However, the result of this study shows that the local investment does not have a significant impact on financial development.

The VAR framework, as discussed before, enables one to gauge more interesting insights on endogeneity issues and indirect effects as well. For instance, Equation (2) as already explained in the methodology section is now analysed and correspond to the third column of Table 2. Hence, referring to the 'FDI' equation, it is observed that a reverse causation exists as well as financial development appears to be also a determinant of FDI. It is found that a $1 \%$ increase in financial development results in $0.17 \%$ increase in FDI inflow. It therefore implies that financial development of the countries play an important role in attracting FDI thus supporting a bi-causal and reinforcing relationship between financial development and FDI. As observed, the most interesting economic scenario suggests a two-way causal link between FDI and financial development. Countries with developed financial sector attract foreign investment. Also, FDI as a dependent variable is highly influenced by some of the control variables. Consequently, it is observed, in terms of magnitude, that past values of FDI, trade openness and economic growth are determinants of FDI. Such results provide insights as to the policies that a country should have in order to attract FDI.

Other interesting results can be observed from the fourth column having GDP as the dependent variable now 
corresponding to equation 3. From the results, it is observed that economic growth of the countries is influenced by FDI. Referring to the emerging literature on foreign direct investment, it is observed that FDI has a positive impact on economic growth and depends on local conditions and absorptive capacities. This result supports the findings of various scholars such as $\mathrm{Li}$ and Liu [25] who found a positive relationship between FDI and economic growth. Moreover, local investment and human capital are also observed to be determinants of economic growth. However, inflation is seen to deter growth.

The impulse response analysis also tends to confirm the main results obtained in general.

\section{Conclusions}

By using a PVAR approach, this empirical study investigates the potential relationship between foreign direct investment and financial market development in selected small island economies over the period 1990-2013. The main findings show that indeed foreign capital is an important determinant for developing the economies financial market. Moreover, even the economic growth has been identified to play a crucial role in boosting financial development for small island economies. The research further examines other relationships like the extent to which financial development encourages foreign capital to flow in the host countries. Indeed, a bi-causal relationship between FDI and FD is obtained according to this study. Moreover, this paper also examines the role played by financial development and FDI in boosting the country's growth rate. It was concluded by the results that foreign presence contributes to economic growth in the countries.

Hence, in terms of policy recommendations the government needs to design policies that will further attract FDI in order to heighten financial development. For example, policy makers should identify the need of foreign capital as they are crucial for the well-functioning of the banking system and capital markets. Moreover, other sectors also benefit from foreign presence in a particular country like educational sector whereby the foreign firms transfer skill and knowhow to the employees of the host countries. Also, policy makers should avoid restrictive policies on profit repatriation and corporate taxes which might discourage foreign direct investors from investing in the country.

\section{References}

[1] McKinnon, R.I. (1973) Money and Capital in Economic Development. Brookings Institution Press, Washington DC.

[2] Kholdy, S. and Sohrabian, A. (2008) Foreign Direct Investment, Financial Markets and Political Corruption. Journal of Economic Studies, 35, 486-500. http://dx.doi.org/10.1108/01443580810916514

King, R.G. and Levine, R. (1993) Finance, Entrepreneurship and Growth. Journal of Monetary Economics, 32, 513542. http://dx.doi.org/10.1016/0304-3932(93)90028-E

[3] Alfaro, L., Chanda, A., Kalemli-Ozcan, S. and Sayek, S. (2004) FDI and Economic Growth: The Role of Local Financial Markets. Journal of International Economics, 64, 89-112. http://dx.doi.org/10.1016/S0022-1996(03)00081-3

[4] Dutta, N. and Roy, S. (2011) Foreign Direct Investment, Financial Development and Political Risks. The Journal of Developing Areas, 44, 303-327. http://dx.doi.org/10.1353/jda.0.0106

[5] Hermes, N. and Lensink, R. (2003) Foreign Direct Investment, Financial Development and Economic Growth. Journal of Development Studies, 40, 142-163. http://dx.doi.org/10.1080/00220380412331293707

[6] Kholdy, S. and Sohrabian, A. (2005) Financial Markets, FDI, and Economic Growth: Granger Causality Test in Panel Data Models. Working Paper, California State Polytechnic University.

[7] Adam, A.M. and Tweneboah, G. (2009) Foreign Direct Investment and Stock Market Development: Ghana’s Evidence. International Research Journal of Finance and Economics, 26, 178-185.

[8] Al Nasser, O.M. and Soydemir, G. (2010) Domestic and International Determinants of Foreign Direct Investment in Latin America. FMA Annual Meeting, New York.

[9] Alfaro, L., Chanda, A., Kalemli-Ozcan, S. and Sayek, S. (2010) Does Foreign Direct Investment Promote Growth? Exploring the Role of Financial Markets on Linkages. Journal of Development Economics, 91, 242-256. http://dx.doi.org/10.1016/j.jdeveco.2009.09.004

[10] Henry, P.B. (2000) Do Stock Market Liberalizations Cause Investment Booms? Journal of Financial Economics, 50, 301-334. http://dx.doi.org/10.1016/S0304-405X(00)00073-8

[11] Rajan, R.J. and Zingales, L. (2003) Saving Capitalism from the Capitalists: Unleashing the Power of Financial Markets to Create Wealth and Spread Opportunity. Princeton University Press, Princeton.

[12] Beck, T., Fuchs, M. and Uy, M. (2009) Finance in Africa: Achievements and Challenges. World Bank Policy Research 
Working Paper 5020. http://dx.doi.org/10.1596/1813-9450-5020

[13] Svaleryd, H. and Vlachos, J. (2005) Financial Markets, the Pattern of Industrial Specialization and Comparative Advantage: Evidence from OECD Countries. European Economic Review, 49, 113-144. http://dx.doi.org/10.1016/S0014-2921(03)00030-8

Wurgler, J. (2000) Financial Markets and the Allocation of Capital. Journal of Financial Economics, 58, 187-214. http://dx.doi.org/10.1016/S0304-405X(00)00070-2

[14] Levine, R. (2001) International Financial Liberalisation and Economic Growth. Review of International Economics, 9, 688-702. http://dx.doi.org/10.1111/1467-9396.00307

[15] Beck, T., Demirgüç-Kunt, A. and Levine, R. (2000) A New Database on the Structure and Development of the Financial Sector. The World Bank Economic Review, 14, 597-605. http://dx.doi.org/10.1093/wber/14.3.597

[16] Seetanah, B., Ramessur, S.T. and Rojid, S. (2009) Financial Development and Economic Growth: New Evidence from a Sample of Island Economies. Journal of Economic Studies, 36, 124-134. http://dx.doi.org/10.1108/01443580910955033

[17] Matadeen, J., Matadeen, J.S. and Seetanah, B. (2011) Financial Development, Financial Openness and Trade Openness: Evidence from Mauritius. ICITI 2011.

[18] Allen, F., Carletti, E., Cull, R., Qian, J. and Senbet, L.W. (2010) The African Financial Development Gap. Working Paper 10-18, Wharton Financial Institutions Center, University of Pennsylvania. http://dx.doi.org/10.2139/ssrn.1362216

[19] Allen, F., Otchere, I. and Senbet, L.W. (2011) African Financial Systems: A Review. Review of Development Finance, 1, 79-113. http://dx.doi.org/10.1016/j.rdf.2011.03.003

[20] Baltagi, B.H., Demetriades, P. and Law, S.H. (2009) Financial Development and Openness: Evidence from Panel Data. Journal of Development Economics, 89, 285-296. http://dx.doi.org/10.1016/j.jdeveco.2008.06.006

[21] Hanh, P.T.H. (2010) Financial Development, Financial Openness and Trade Openness: New Evidence. CARE-EMR, University of Rouen, Rouen.

[22] Zouheir, A. and Nahed, Z. (2014) Financial Development, Trade Openness and Economic Growth in North African Countries. The Romanian Economic Journal, Year XVII No. 53.

[23] Outreville, F.J. (1999) Financial Development, Human Capital and Political Stability. UNCTAD Discussion Paper 142, United Nations Conference on Trade and Development, Geneva, Switzerland Political Corruption. Journal of Economic Studies, 35, 486-500.

[24] Bittencourt, M. (2011) Inflation and Financial Development: Evidence from Brazil. Economic Modelling, 28, 91-99. http://dx.doi.org/10.1016/j.econmod.2010.09.021

[25] Li, X. and Liu, X. (2005) Foreign Direct Investment and Economic Growth: An Increasingly Endogenous Relationship. World Development, 33, 393-407. http://dx.doi.org/10.1016/j.worlddev.2004.11.001 